\title{
KAIDAH INTERAKSI KOMUNIKASI TRADISI LISAN BASIACUANG DALAM ADAT PERKAWINAN MELAYU KAMPAR RIAU
}

\author{
Nova Yohana \\ Fakultas Ilmu Sosial Ilmu Politik, Jurusan Komunikasi, Universitas Riau Pekanbaru - 28293 \\ Telp/Fax/HP (0761) 632677, 35675, 081320033210. Email: nova.yo7@ gmail.com. \\ Kurnia Husmiwati \\ Fakultas Ilmu Sosial Ilmu Politik, Jurusan Komunikasi, Universitas Riau Pekanbaru - 28293 \\ Telp/Fax/HP (0761) 632677, 35675, 085363844778. Email: kwati32@ rocketmail.com. \\ Naskah diterima tanggal 28 April 2015, direvisi tanggal 22 Mei 2015, disetujui tanggal 22 Juni 2015
}

\section{RULES OF COMMUNICATION INTERACTION BASIACUANG ORAL TRADITION IN TRADITIONAL MARRIAGE MALAY KAMPAR RIAU}

\begin{abstract}
Basiacuang verbal tradition in the traditional marriage ceremony in the Kampar Malay speech community in Kuok village, Kuok Subdistrict, Kampar District in Riau province, is a part of the customs and traditions inherited from ancestors. This tradition is organized as a performance, and it has a social function in the Kampar Malay community. The problem in this research is how the rules of communicative interaction of basiacuang verbal tradition in the Malay Riau marriage ceremony. This study is purposed to determine the linguistic rules, interaction rules, and cultural norms in performance of basiacuang verbal tradition in the traditional marriage ceremony of Malay Kampar custom. The method used is a qualitative method to ethnography approach of communication. Data were collected through observation, interviews, and documentation. The results of this study showed that the linguistic rules of Basiacuang verbal tradition prioritize the beauty of language usage that conveyed by the speaker. Whether the interaction rules of speech in basiacuang tradition, success or fail depending on the ability and the fluency of the speaker in applying the value. Culture rules in basiacuang is in which every utterance contains of proverbs and rhymes that have a philosophical meaning, values and norms in the Kampar Malay life community.
\end{abstract}

Keywords: communicative interaction, basiacuang verbal tradition, marriage tradition ceremony.

\begin{abstract}
Abstrak
Tradisi lisan basiacuang dalam upacara adat perkawinan pada masyarakat tutur Melayu Kampar di Desa Kuok, Kecamatan Kuok, Kabupaten Kampar, Provinsi Riau merupakan bagian adat dan tradisi yang diwarisi secara turun temurun dari nenek moyang terdahulu. Tradisi ini berbentuk pertunjukan dan berfungsi sosial dalam masyarakat Melayu Kampar. Permasalahan dalam penelitian ini adalah bagaimana kaidah interaksi komunikasi tradisi lisan basiacuang pada Upacara Adat Perkawinan Melayu Kampar Riau. Penelitian ini bertujuan untuk mengetahui kaidah linguistik, kaidah interaksi sosial, dan kaidah budaya dalam pertunjukan tradisi lisan basiacuang pada upacara perkawinan adat Melayu Kampar. Metode yang digunakan adalah metode kualitatif dengan pendekatan etnografi komunikasi. Data dikumpulkan melalui observasi,
\end{abstract}


wawancara, dan dokumentasi. Hasil penelitian ini menunjukkan bahwa kaidah linguistik tradisi lisan basiacuang mengutamakan keindahan pemakaian bahasa yang disampaikan penutur. Kaidah interaksi sosial pada tuturan dalam tradisi basiacuang berhasil atau tidaknya tergantung dari keahlian dan kefasihan penutur dalam menerapkan nilai-nilai dalam basiacuang. Kaidah budaya dalam basiacuang dimana setiap tuturan berisi tentang ungkapan petatah-petitih dan juga pantun yang memunyai makna filosofi, nilai-nilai, dan norma-norma dalam kehidupan masyarakat Melayu Kampar.

Kata kunci: interaksi komunikasi, tradisi lisan basiacuang, upacara adat perkawinan.

\section{PENDAHULUAN}

Tradisi lisan merupakan salah satu bentuk ekspresi kebudayaan daerah dan merupakan bagian kekuatan kultural suatu bangsa. Tradisi lisan sangat beraneka ragam bentuknya, tidak hanya berupa dongeng, mitos, dan legenda atau pantun dan syair. Tradisi lisan adalah sesuatu yang dituturkan masyarakat (Lord, 2000). Di dalam tradisi lisan terkandung berbagai hal yang menyangkut hidup dan kehidupan masyarakat pendukungnya pada masa itu, seperti kearifan lokal, sistem nilai, sejarah, hukum, adat, dan pengobatan (Kleden, 2004).Tradisi lisan pada upacara adat merupakan alat komunikasi yang digunakan oleh komunitas adat untuk menyampaikan maksud sesuai dengan bahasa adat dan aturan adat yang berlaku.

Basiacuang adalah salah satu bentuk tradisi lisan kebudayaan masyarakat suku Melayu Kampar di Provinsi Riau. Tradisi lisan ini berbentuk pertunjukkan untuk menyampaikan maksud dan tujuan secara terselubung, simbolik, dan biasanya dituturkan dalam rangka upacara adat masyarakat Melayu Kampar. Tuturan ini dipakai oleh Ninik Mamak, Datuk, dan golongan orang-orang Adat Melayu Kampar. Pada hakikatnya, bahasa yang digunakan dalam kegiatan basiacuang dipahami sebagai ungkapan pesan yang dinyatakan dalam bentuk perumpamaan, petatah-petitih, pantun, dan kiasan adat yang dituturkan seorang penutur sehingga memberikan nilai keindahan dalam kegiatan basiacuang tersebut. Kalimatkalimat maupun ungkapan dalam basiacuang menjadi pesan tersendiri bagi penutur dan pendengarnya karena berfungsi sosial dan memunyai makna filosofi bagi kehidupan masyarakat Melayu Kampar.

Menurut Zulfa (2012) basiacuang berasal dari kata siacuang dan "acuang" berarti meninggikan atau sanjung menyanjung. Istilah siacuang berasal dari bahasa Arab, artinya takzim, membesarkan atau menyanjung. Meninggikan orang lain dalam arti menyanjung atau menghargai orang lain dalam berkomunikasi dengan bersikap rendah hati dan tidak sombong (Syarfi, dkk, 2011). Pada zaman dahulu setiap upacara adat dianggap tidak sah apabila tidak disampaikan dengan tuturan basiacuang. Basiacuang merupakan suatu bahasa dalam adat istiadat pergaulan Datuk dengan Datuk dan Ninik Mamak dengan kemenakannya. Begitu pentingnya tuturan ini, sehingga tidak ada upacara adat yang dilakukan tanpa basiacuang. Basiacuang merupakan nilai dalam setiap kehidupan masyarakat Melayu Kampar (Zulfa, 2012).

Masyarakat Desa Kuok, Kecamatan Kuok, Kabupaten Kampar merupakan bagian dari masyarakat tutur Melayu Kampar yang sampai saat ini masih menggunakan tradisi atau budaya lisan basiacuang terutama dalam upacara adat perkawinan. Pada waktu upacara adat perkawinan hampir semua penggunaan basiacuang dimulai dari ketika mengantar tanda bertunangan, kato ulu jawek tando (kata serah terima tanda), kata minta izin untuk menghidangkan jambau dan membuka selo atau memohon diri untuk pulang (Husmiwati, 2015). Basiacuang merupakan pembicaraan dua pihak, dimulai dari pihak keluarga yang datang (pihak laki-laki), dan merupakan formula bagi pihak yang menanti (pihak perempuan) untuk menyampaikan maksud dan tujuan dengan hormat. Pihak keluarga 
yang datang (pihak laki-laki) memakai tuturan bertanya sedangkan pihak yang menanti (pihak perempuan) memakai jawaban tuturan basiacuang. Tuturan basiacuang dijawab dengan mengulang perumpamaan dari bentuk tuturan yang disampaikan dari pihak yang datang. Dengan demikian basiacuang tercipta secara spontan dari pihak yang datang, sementara pihak penerima mengombinasi dengan pantun yang dibuat seketika karena telah memiliki perbendaharaan kata yang hidup dalam ingatan dan digunakan suatu pola rima, perumpamaan, dan pantun agar tujuan kedatangan pihak laki-laki jelas. Dalam menyatakan hal tersebut dipergunakan bahasa yang puitis atau bahasa yang baik untuk didengar.

Proses penciptaan kelisanan tercipta dalam konteks budaya tradisional. Konsep budaya tradisional sangat mementingkan kesopanan dalam berbahasa, dan ketertiban dalam berkomunikasi. Hal ini terlihat pada penciptaan tuturan basiacuang, yang berisi nilai kesopanan dan kelancaran dalam berkomunikasi dengan masyarakat dan kaum adat Desa Kuok, Kecamatan Kuok, Kabupaten Kampar, Provinsi Riau. Dalam tradisi basiacuang ini seorang Ninik Mamak lah yang memiliki peran utama menyangkut anak kemenakan. Hal ini dikarenakan tradisi basiacuang merupakan kebudayaan dalam masyarakat Melayu Kampar dengan sistem kekerabatannya yang disebut matrilineal. Dalam sistem kekerabatan ini harta pusaka, gelar, dan nama kesukuan turun dari silsilah garis ibu. Saudara laki-laki dari ibu disebut Ninik Mamak. Ninik Mamak bertanggungjawab atas kerukunan, keselamatan keluarganya dan kemenakannya. Dalam adat perkawinan Ninik Mamak bertugas mencari urang sumando hingga kemenakannya berumahtangga. Dalam hal ini bukan berarti Ninik Mamak lepas tanggung jawabnya atas keluarga, tapi justru di sinilah ditentukan kewibawaan dan kebijaksanaan Ninik Mamak dalam membimbing anak kemenakannya (Husmiwati, 2015).

Setiap daerah memiliki tradisi lisan yang mengandung kearifan lokal. Tradisi lisan basiacuang tidak dapat dipisahkan dari komunitas penuturnya. Penelitian ini menggunakan pendekatan etnografi komunikasi untuk meninjau penggunaan bahasa dalam interaksi lisan. Kajian etnografi komunikasi menyentuh aspek budaya masyarakat penutur suatu bahasa. Etnografi komunikasi memandang perilaku komunikasi sebagai perilaku yang terlahir dari integrasi tiga keterampilan yang dimiliki setiap individu sebagai makhluk sosial. Ketiga keterampilan ini terdiri dari keterampilan linguistik, keterampilan interaksi sosial, dan keterampilan budaya (Kuswarno, 2011).

Berdasarkan uraian tersebut di atas, peneliti merumuskan masalah yakni: Bagaimana kaidah interaksi komunikasi tradisi lisan basiacuang dalam upacara adat perkawinan masyarakat tutur Melayu Kampar Riau?. Tujuan penelitian ini adalah diperolehnya gambaran lengkap tentang kaidah linguistik, kaidah interaksi sosial, dan kaidah budaya pada tuturan komunikasi tradisi lisan basiacuang dalam upacara adat perkawinan Melayu Kampar Riau. Kontribusi yang didapatkan dari penelitian ini adalah menambah pengembangan teoretis terhadap kajian etnografi komunikasi pada masyarakat tutur. Pada sisi lain hasil penelitian dapat memberikan gambaran pola komunikasi budaya dalam suatu tradisi lisan yang mencakup keterampilan linguistik, keterampilan interaksi, dan keterampilan budaya. Secara metodologis hasil penelitian ini dapat digunakan sebagai pijakan dasar untuk penelitian selanjutnya mengenai etnografi komunikasi pada suatu masyarakat tutur.

\section{LANDASAN KONSEP}

\section{Penelitian Terdahulu}

Beberapa penelitian terdahulu mengenai tradisi lisan yang ada relevansinya dengan penelitian ini telah dilakukan oleh peneliti sebelumnya. Melalui pemaparan penelitian terdahulu penulis juga dapat memosisikan penelitian ini sehingga akan memerlihatkan tingkat orisinalitas dari penelitian yang dilakukan. 


\section{Tabel 1}

Perbedaan Penelitian Kaidah Interaksi Komunikasi Tradisi Lisan Basiacuang dalam Adat Perkawinan Melayu Kampar Riau dengan Penelitian Terdahulu

\begin{tabular}{|c|c|c|c|}
\hline & \multicolumn{3}{|c|}{ Judul Penelitian } \\
\hline & $\begin{array}{c}\text { Komunikasi Ritual Natoni } \\
\text { Masyarakat Adat Boti } \\
\text { Dalam Di Nusa Tenggara } \\
\text { Timur }\end{array}$ & $\begin{array}{c}\text { Pemolaan Komunikasi } \\
\text { Tradisi Basiacuang Sebagai } \\
\text { Bentuk Kearifan Lokal } \\
\text { dalam Upacara Pernikahan } \\
\text { Masyarakat Melayu } \\
\text { Kampar }\end{array}$ & $\begin{array}{c}\text { Kaidah Interaksi } \\
\text { Komunikasi Tradisi Lisan } \\
\text { Basiacuang pada Adat } \\
\text { Perkawinan Melayu } \\
\text { Kampar Riau }\end{array}$ \\
\hline Penulis & Petrus Ana Andung & Kurnia Husmiwati & $\begin{array}{c}\text { Nova Yohana dan Kurnia } \\
\text { Husmiwati }\end{array}$ \\
\hline $\begin{array}{l}\text { Deskripsi } \\
\text { Penelitian }\end{array}$ & $\begin{array}{l}\text { Suku Boti masih menggunakan } \\
\text { natoni sebagai media } \\
\text { komunikasi tradisional } \\
\text { mereka. Media ini digunakan } \\
\text { secara lisan dalam puisi } \\
\text { tradisional hampir di setiap } \\
\text { acara formal. Seni tradisional } \\
\text { ini tidak hanya sekedar untuk } \\
\text { menransfer pesan melainkan } \\
\text { untuk budaya berbagi, } \\
\text { membuat asosiasi, dan } \\
\text { hubungan dalam rangka untuk } \\
\text { memiliki sebuah komunitas } \\
\text { utuh. }\end{array}$ & $\begin{array}{l}\text { Tradisi basiacuang merupakan } \\
\text { budaya lisan sebagai bentuk } \\
\text { kearifan lokal masyarakat } \\
\text { Melayu Kampar dan perlu } \\
\text { dipertahankan dalam } \\
\text { modernisasi sekarang ini. } \\
\text { Tradisi basiacuang sebagai } \\
\text { salah satu identitas masyarakat } \\
\text { Melayu Kampar mengandung } \\
\text { nilai-nilai dan norma-norma } \\
\text { budaya yang masih digunakan } \\
\text { dalam upacara pernikahan. }\end{array}$ & $\begin{array}{l}\text { Tradisi atau budaya lisan } \\
\text { basiacuang saat ini masih } \\
\text { digunakan dalam } \\
\text { perkawinan masyarakat tutur } \\
\text { Melayu Kampar. Kalimat- } \\
\text { kalimat dalam basiacuang } \\
\text { menjadi pesan tersendiri bagi } \\
\text { penutur dan pendengarnya } \\
\text { karena berfungsi sosial dan } \\
\text { mempunyai makna filosofi } \\
\text { bagi kehidupan masyarakat } \\
\text { Melayu Kampar. }\end{array}$ \\
\hline $\begin{array}{l}\text { Fokus } \\
\text { Penelitian }\end{array}$ & $\begin{array}{l}\text { Praktik komunikasi ritual } \\
\text { masyarakat adat Boti } \text { Dalam } \\
\text { melalui natoni. }\end{array}$ & $\begin{array}{l}\text { Pemolaan dari aktivitas } \\
\text { komunikasi tradisi basiacuang } \\
\text { yang terjadi secara berulang } \\
\text { dalam upacara pernikahan } \\
\text { masyarakat Melayu Kampar } \\
\text { Provinsi Riau sebagai bentuk } \\
\text { kearifan lokal }\end{array}$ & $\begin{array}{l}\text { Kaidah interaksi komunikasi } \\
\text { tradisi lisan basiacuang dalam } \\
\text { adat perkawinan masyarakat } \\
\text { Melayu Kampar dengan } \\
\text { perspektif } \\
\text { komunikasi }\end{array}$ \\
\hline $\begin{array}{l}\text { Tujuan } \\
\text { Penelitian }\end{array}$ & $\begin{array}{l}\text { Mengidentifikasikan fungsi } \\
\text { menggunakan natoni dalam } \\
\text { perspektif ritual komunikasi }\end{array}$ & $\begin{array}{l}\text { Mengkaji situasi komunikasi, } \\
\text { peristiwa komunikasi, dan } \\
\text { tindak komunikasi pada tradisi } \\
\text { lisan basiacuang yang terjadi } \\
\text { secara berulang dalam upacara } \\
\text { adat pernikahan masyarakat } \\
\text { Melayu Kampar Provinsi Riau }\end{array}$ & $\begin{array}{l}\text { Mengungkapkan } \\
\text { linguistik, kaidah interaksi } \\
\text { sosial, dan kaidah budaya } \\
\text { penggunaan tradisi lisan } \\
\text { basiacuang oleh masyarakat } \\
\text { tutur Melayu Kampar Riau } \\
\text { dalam adat perkawinan. }\end{array}$ \\
\hline $\begin{array}{l}\text { Pendekatan } \\
\text { Penelitian }\end{array}$ & Etnometodologi & Etnografi Komunikasi & Etnografi Komunikasi \\
\hline
\end{tabular}

Sumber: diolah dari berbagai sumber.

\section{Bahasa, Komunikasi, dan Kebudayaan}

Setiap masyarakat akan memiliki sistem komunikasi sendiri-sendiri, maka dengan sendirinya demi kelangsungan hidupnya, setiap masyarakat dapat membentuk kebudayaannya. Bahasa menjadi inti dari komunikasi sekaligus sebagai pembuka realitas bagi kehidupan manusia. Kemudian dengan komunikasi, manusia membentuk masyarakat dan kebudayaannya. Bahasa berfungsi sebagai suatu mekanisme untuk berkomunikasi dan sekaligus sebagai pedoman untuk melihat realitas sosial, karena bahasa dapat memengaruhi persepsi, menyalurkan dan turut membentuk pikiran (Nugroho, Lestari, dan Wiendijarti, 2012).

Kebudayaan mencakup semua hal yang dimiliki bersama oleh suatu masyarakat. Kebudayaan merupakan pandangan hidup dari sekelompok orang dalam bentuk perilaku, kepercayaan, nilai, dan simbolsimbol yang mereka terima tanpa sadar atau 
tanpa dipikirkannya yang semua diwariskan melalui proses komunikasi dan peniruan dari satu generasi kepada generasi berikutnya (Liliweri, 2003). Manusia melalui komunikasi berusaha memenuhi kebutuhan hidupnya, yang berarti bahwa perilaku komunikasi merupakan bagian dari perilaku ideal yang dirumuskan dalam norma-norma budaya. Konsekuensinya, budaya merupakan landasan komunikasi (Nasrullah, 2012). Bila budaya beranekaragam, maka beranekaragam pula praktik-praktik komunikasi (Mulyana, 2010). Dengan demikian yang dimaksud kebudayaan adalah komunikasi, karena kebudayaan tidak dapat dipisahkan dari komunikasi.

Dari sekian banyak kegunaan budaya, pakar antropologi budaya percaya bahwa bahasalah yang memegang peranan utama dalam perkembangan budaya manusia. Hal ini karena bahasa merupakan wahana utama untuk meneruskan adat-istiadat dari generasi yang satu ke generasi yang lainnya.

Kaitan antara bahasa, komunikasi, dan kebudayaan melahirkan hipotesis realivitas linguistic dari Safir dan Whorf, yang berbunyi "struktur bahasa atau kaidah berbicara suatu budaya akan menentukan perilaku dan pola dalam budaya tersebut." Bahasa menjadi unsur utama sebuah kebudayaan, karena bahasa akan menentukan bagaimana masyarakat penggunanya mengategorikan pengalamannya (Kuswarno, 2011).

Dengan kata lain makna budaya yang mendasari kehidupan masyarakat terbentuk dari hubungan antara simbol-simbol/bahasa. Bahasa hidup dalam komunikasi untuk menciptakan budaya, kemudian budaya itu sendiri yang pada akhirnya akan menentukan sistem komunikasi dan bentuk bahasa seperti apa yang pantas untuknya.

\section{Etnografi Komunikasi}

Etnografi komunikasi secara ilmiah, membahas bahasa, komunikasi, dan kebudayaan dalam satu konteks dan pada satu kelompok masyarakat tertentu. Sehingga etnografi komunikasi tidak hanya membahas kaitan antara bahasa dan komunikasi saja, atau kaitan antara bahasa dan kebudayaan, melainkan membahas ketiganya secara sekaligus. Komunikasi etnografi mengambil bahasa sebagai bentuk budaya sosial untuk mengakui dan menganalisis kode itu sendiri dan proses kognitif penutur dan lawan tutur, yang memang konstitutif dalam banyak budaya (Muriel, 2003).

Etnografi komunikasi menyebutkan ketiga keterampilan ini sebagai kompetensi berkomunikasi (Kuswarno, 2011). Melalui penjelasan tersebut dapat digambarkan model komunikasi etnografi komunikasi, sebagai sebuah model untuk melihat perilaku komunikasi dalam sebuah peristiwa komunikasi seperti tampak pada gambar 1 .

Apabila digambarkan kerangka pemikiran penelitian ini menurut perspektif etnografi komunikasi seperti tampak pada gambar 2.

\section{METODE PENELITIAN}

Metode yang digunakan dalam penelitian ini adalah metode kualitatif dengan pendekatan etnografi komunikasi. Menurut Ruslan (2010), penelitian kualitatif adalah tradisi tertentu dalam ilmu pengetahuan sosial yang secara fundamental bergantung dari pengamatan pada manusia baik kawasannya maupun dalam peristiwa lainnya. Pendekatan etnografi komunikasi digunakan untuk menuntun peneliti memahami bagaimana makna bahasa, komunikasi, dan kebudayaan saling bekerja sama untuk menghasilkan perilaku komunikasi yang khas dalam penggunaan tradisi lisan basiacuang pada adat perkawinan masyarakat tutur Melayu Kampar.

Penelitian ini dilakukan di Desa Kuok, Kecamatan Kuok, Kabupaten Kampar Riau. Objek penelitian ini adalah kaidah linguistik, kaidah interaksi sosial, dan kaidah budaya pada penggunaan tradisi lisan masyarakat tutur Melayu Kampar, Desa Kuok dalam adat perkawinan. 


\section{Tabel 2}

Informan Penelitian

\begin{tabular}{cll}
\hline No & \multicolumn{2}{c}{ Nama Informan } \\
& & \\
\hline 1. & H.H Y. & Dt. Paduko Tuan (Ninik Mamak persukuan Domo) \\
2. & H.Kh & Dt. Penghulu Besar (Ninik Mamak persukuan Melayu) \\
3. & H.Ib. HS & Dt. Paduko Jo Besar (Ninik Mamak persukuan piliang) \\
4. & Yur & Dt. Besar (Ninik Mamak persukuan Melayu Kampai) \\
5. & H. Abd & Dt. Laksamanao (Ninik Mamak persukuan Melayu Mandailing) \\
6. & Nas & Tokoh Masyarakat \\
7. & Amr & Tokoh Masyarakat \\
8. & Sya & Sumondo \\
\hline
\end{tabular}

Sumber: Hasil Penelitian 2014.

Aspek Linguistik

Tindak Ujar Tindak Ujar Tindak Ujar

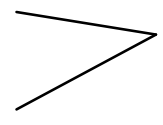

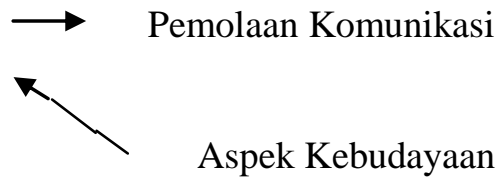

Aspek Interaksi Sosial

Gambar 1 Model Etnografi Komunikasi

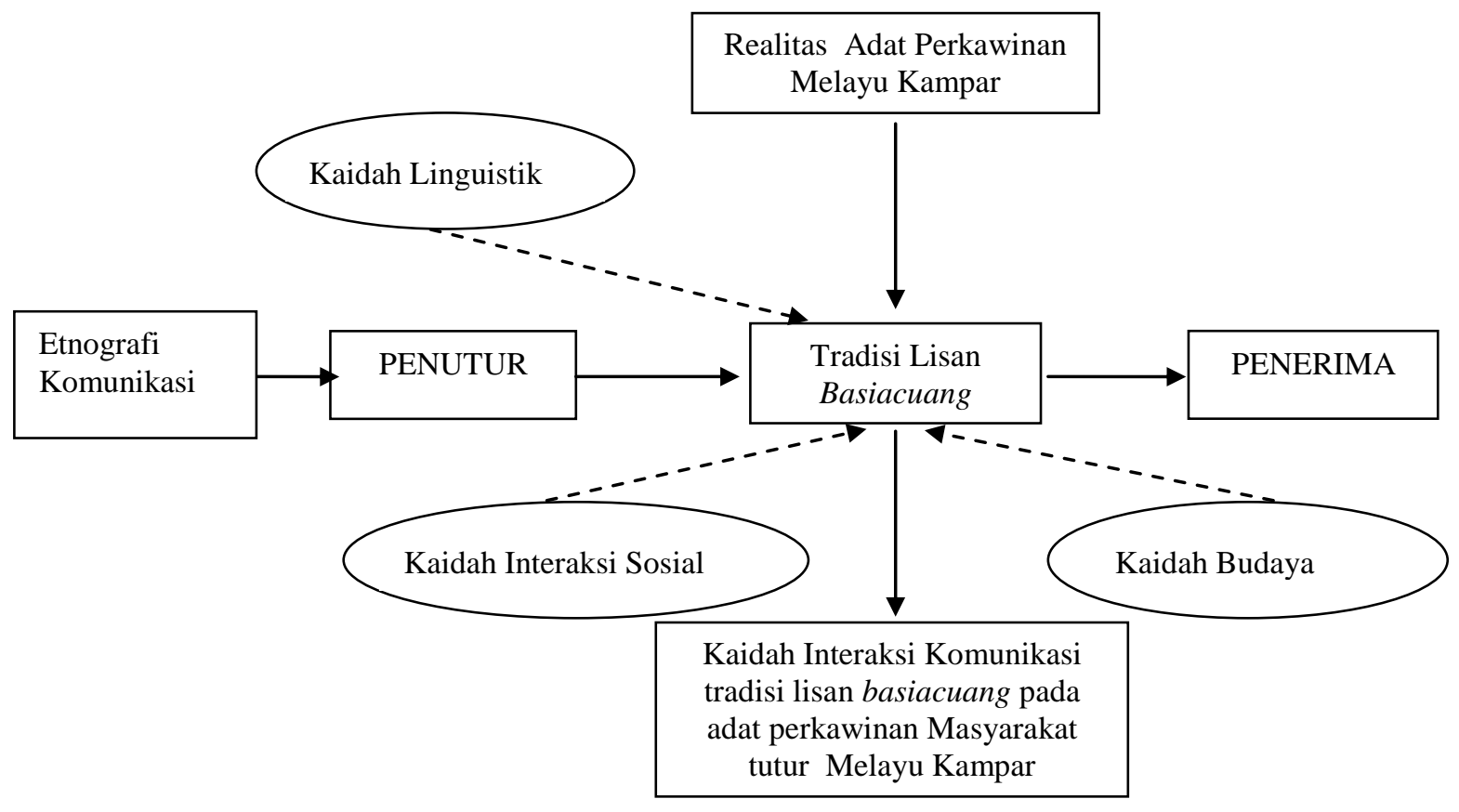

Gambar 2

Kerangka Pemikiran 
Informan penelitian ini ditentukan dengan menggunakan teknik purposif sampling, dengan kriteria informan adalah orang-orang yang terkait langsung dalam upaya melestarikan tradisi basiacuang dalam adat perkawinan masyarakat tutur Melayu Kampar. Menurut Maleong (2005) penelitian kualitatif pada umumnya mengambil jumlah informan yang lebih kecil dibandingkan dengan bentuk penelitian lainnya. Informan dapat dilihat pada tabel 2. Teknik pengumpulan data menggunakan wawancara (indepth interviews), observasi, dokumentasi, dan studi pustaka. Analisis data yang digunakan menggunakan model interaktif Miles dan Huberman (2007) melalui tiga komponen yaitu reduksi data, penyajian data, dan verfikasi atau penarikan kesimpulan.

\section{HASIL PENELITIAN DAN PEMBAHASAN}

\section{Kaidah Linguistik dalam Tradisi Basiacuang pada Adat Perkawinan Melayu Kampar}

Bahasa merupakan alat bagi orangorang untuk berinteraksi dengan orang lain dan juga sebagai alat berfikir. Maka bahasa berfungsi sebagai suatu mekanisme untuk berkomunikasi dan sekaligus sebagai pedoman untuk melihat realitas sosial, karena bahasa dapat memengaruhi persepsi, menyalurkan, dan turut membentuk pikiran (Nugroho, Lestari, dan Wiendijarti, 2012).

Bahasa juga berfungsi sebagai suatu mekanisme untuk berkomunikasi dan sekaligus sebagai pedoman untuk melihat realitas sosial, karena bahasa dapat memengaruhi persepsi, menyalurkan, dan turut membentuk pikiran (Nugroho, Lestari, dan Wiendijarti, 2012).

Aspek linguistik mencakup elemenelemen verbal, non verbal, pola elemenelemen dalam peristiwa tutur tertentu, rentang varian yang mungkin, dan makna varianvarian dalam situasi tertentu (Kuswarno, 2011).

Latar belakang dari sistem linguistik (tata bahasa) dari setiap bahasa bukan hanya suatu alat reproduksi untuk menyampaikan gagasan, tetapi lebih sebagai pembentuk gagasan, pembentuk dan pemandu bagi aktivitas mental individu, untuk menganalisis kesan, untuk menyintesiskan aktivitas mental dalam komunikasi.

Basiacuang tidak dapat dipisahkan dari komunitas si penuturnya. Semua persukuan di Desa Kuok memakai tradisi basiacuang dalam adat perkawinan masyarakat Melayu Kampar. Penutur basiacuang menjadi juru bicara yang mewakili pihak keluarga laki-laki maupun keluarga perempuan. Di sinilah nantinya peran Ninik Mamak dalam basiacuang. Seperti yang diungkapkan oleh seorang Ninik Mamak bahwa:

"Ketika acara adat dalam pernikahan pihak keluarga laki-laki, dengan menghadirkan seseorang penutur, berhadapan dengan pihak keluarga perempuan. Demikian pula, pihak keluarga perempuan pun menghadirkan seorang penutur basiacuang untuk mewakili mereka berkomunikasi dengan pihak keluarga laki-laki, dan inilah peran kami sebagai Ninik Mamak. Ninik Mamak di sini yaitu seorang penutur yang andal dalam persukuannya. Orang yang pandai basiacuang akan diberikan tempat yang istimewa karena ia akan menerima orang datang (tamu) ketika ada helat adat (upacara). Orang yang pandai basiacuang dipandang lebih baik oleh masyarakat, seorang penutur basiacuang di dalam dirinya sudah tertanam nilai-nilai filosofi luhur sesuai alur yang patut (sesuai nilai dan norma)". (Wawancara dengan Datuk Penghulu Besar kepala persukuan Melayu Sumpu, 08 September 2014).

Setiap tuturan dalam basiacuang memiliki makna dan arti-arti tersendiri. Si penutur basiacuang mengambil perumpamaan dari alam flora dan fauna, hutan pantai maupun pengalaman yang pernah dialami oleh si penutur basiacuang itu sendiri. Dalam tuturan inilah basiacuang tercipta dengan sendirinya Hal ini membuktikan bahwa tradisi lisan tidak dapat dipisahkan dari masyarakat sebagai pemilik tradisi basiacuang. Berikut ini teks lisan 
basiacuang dalam adat perkawinan masyarakat tutur Melayu Kampar yang memuat kata kiasan, perumpamaan dan ibarat:

Lasiang ghuponyo aghi, latoghang puntuong jo asok, ladatang ghuponyo kami, nak batanyo kami kaaciok/Datuk ado unghang datang, Adat yang mambate Sarak yang malarang, ada ughang yang melambai. Maknanya adalah sudah datang rupanya pihak laki-laki kepada pihak perempuan yang ingin bertanya kepada Ninik Mamak pihak perempuan (pihak yang menanti) memohon izin kepada seluruh yang hadir dalam acara tersebut untuk menyampaikan maksud dan tujuan. (Wawancara dengan Datuk Penghulu Besar kepala persukuan Melayu Sumpu 12 September 2014).

Pada pelaksanaan tradisi lisan basiacuang saat upacara perkawinan selain penggunaan pesan verbal juga didukung pesan non verbal dari penutur. Juru bicara (penutur) duduk dengan bersila atau bersimpuh seperti duduk seorang laki-laki begitu juga tamu laki-laki yang datang. Kepala persukuan sebagai penutur sedikit menundukkan kepalanya, dan bertutur kata yang halus dan sopan. Penutur sering menggenggam kedua tangannya dan ada juga meletakkan kedua tanggannya di atas lututnya (Husmiwati, 2014).

Dalam adat perkawinan tepak sirih wajib dibawa secara adat, yang berisikan sirih, gambir, pinang sadah, yang tersusun dalam tepak sirih, dan menjadi syarat utama dalam upacara adat perkawinan karena akan disebut tidak beradat sebuah acara kalau tidak ada sirih di ketengahkan. Ninik Mamak memulai basiacuang dengan berpetatah petitih menyampaikan hormat dan penghargaan sambil menyuguhkan sekapur sirih. Berikut teks lisan basiacuang saat mengantarkan tepak sirih dalam adat perkawinan masyarakat tutur Melayu Kampar:

Satantang sirih manyirih kami ado tepak nan sabuah bakawal boke keramat minta boke nan bulio ndak ado nan codiok pado mamak, mamak bapisan tajam kamanakan bahu gantiong kini kok lapatuik kami sirikan tepak nan sabuah kapalo alek nan datang sakitu kato disampaikan. Maknanya adalah Ninik Mamak pihak laki-laki mengulurkan tepak sirih kepada Ninik Mamak pihak perempuan, karena sirih memiliki lambang sifat rendah hati, memberi, serta memuliakan orang. Peristiwanya pihak orang yang datang (pihak laki-laki) melakukan prosesi penyerahan tepak kepada orang yang menanti (pihak perempuan). pihak lakilaki menyuguhkan sirih kepada tuan rumah dan meminta Datuk Paduko Besar pihak perempuan untuk melihat, mengambil, dan memakan sirih tersebut, sebagai rasa penghargaan terhadap orang lain, simbol tepak melambangkan rasa tulus hati dalam menyambut tamu dan juga sebagai lambang persaudaraan". (Wawancara dengan Datuk Penghulu Besar kepala persukuan Melayu Kampai 08 September 2014).

Menurut Bustami dalam tuturan basiacuang ada beberapa pantun untuk memperindah tuturan. Jadi jika audiens sudah mulai berbisik-bisik maka tuturannya dianggap tidak menarik lagi. $\mathrm{Si}$ penutur langsung merespon situasi ini dan penutur mulai memperindah tuturan dengan menambahkan pantun. Artinya audiens memunyai pengaruh besar bagi si penutur untuk menentukan apakah tuturannya bagus dan indah (Zulfa, 2012).

\section{Kaidah Interaksi (Rules of Interaction) Sosial dalam Tradisi Basiacuang pada Adat Perkawinan Melayu Kampar}

Komunikasi adalah interaksi, di mana yang menghubungkan setiap manusia adalah komunikasi. Pada saat seseorang berinteraksi dengan orang lain pasti akan menciptakan sebuah komunikasi, baik verbal maupun non verbal. Melalui komunikasi dan interaksi dengan manusia-manusia lainnya semua kebutuhan akan terpenuhi dan tujuan pun akan tercapai. Begitu juga dalam satu komunitas budaya, apabila tiap individunya tidak berinteraksi dan berkomunikasi mustahil akan tercapai tujuannya. 
Tradisi basiacuang merupakan kebudayaan kekerabatan dalam budaya Kampar. Masyarakat Melayu Kampar terkenal dengan sistem kekerabatannya yang disebut dengan matrilineal dengan segala keunikan adat istiadatnya. Dalam sistem kekerabatan ini, harta pusaka, gelar, dan nama kesukuan turun temurun menurut silsilah garis ibu. Saudara laki-laki dari ibu disebut Ninik Mamak yang dituakan. Ninik Mamak yaitu yang memegang pimpinan dalam keluarga. Ninik Mamak bertanggungjawab atas kerukunan dan kesejahteraan para saudara dan kemenakannya serta keselamatan harta pusaka.

Dalam adat pernikahan Ninik Mamak bertugas mencari orang sumando hingga kemenakannya berumahtangga. Dalam hal ini bukan berarti seorang Ninik Mamak lepas tanggung jawabnya atas keluarga, tapi justru di sinilah ditentukan kewibawaan dan kebijaksanaan seorang Ninik Mamak dalam membimbing anak kemenakannya.

Kaidah interaksi mencakup penjelasan tentang kaidah-kaidah penggunaan tutur yang bisa diterapkan pada peristiwa komunikasi. Kaidah interaksi mengacu pada ketentuan tentang bagaimana orang harus bertindak dalam hubungannya dengan nilai-nilai yang diketahui oleh masyarakat tutur (Kuswarno, 2011).

Dalam hal ini aspek interaksi sosial mencakup persepsi ciri-ciri penting dalam komunikatif, seleksi, dan interprestasi bentukbentuk yang tepat untuk situasi, peran, dan hubungan tertentu (kaidah untuk penggunaan ujaran), norma-norma interaksi dan interprestasi, dan strategi untuk mencapai tujuan.

Syukur dalam Kuswarno (2011) menjelaskan hal tersebut dengan rules theory di mana asumsi dasar dari rules theory adalah perilaku sosial tersusun dan terorganisasi. Perilaku-perilaku tertentu akan berulang pada situasi yang hampir sama, namun meskipun terorganisasi, pola-pola interaksi sosial tersebut akan bervariasi pada situasi yang berbeda karena sifatnya yang tidak universal, melainkan sangat kontekstual. Jadi rules theory menekankan pada hubungan antara cara-cara orang berperilaku dengan budaya dan situasi di mana perilaku itu terjadi. Rules theory ini pun sangat mendukung dan saling melengkapi dalam studi interaksi simbolik. Symbolic interactionism arti penting dari interaksi dan makna dalam kehidupan manusia, sedangkan rules theory memberikan bentuk dan substansi pada hubungan interaksi makna ini.

Untuk mengetahui suatu aturan yang tepat, seseorang harus mengenal konteksnya dan perilaku yang diwajibkan, disukai ataupun dilarang. Aturan juga harus dinyatakan dalam suatu bentuk yang menunjukkan bahwa aturan tersebut memungkinkan untuk ditaati. Tahapan kaidah interaksi tradisi lisan basiacuang dalam adat perkawinan masyarakat tutur Melayu Kampar Desa Kuok dapat dilihat pada tabel 3.

Basiacuang ini dilakukan di dalam rumah pihak perempuan, yang dihadiri oleh orang laki-laki saja. Semua yang hadir duduk sesuai dengan adat bersila dan bersimpuh ini memperlihatkan bagaimana sopan santun duduk bersama orang lain. Seperti disampaikan oleh tokoh adat masyarakat bahwa :

"Basiacuang dalam pernikahan ini hanya dihadiri oleh orang laki-laki saja, oleh Ninik Mamak dalam persukuannya karena mereka yang bertanggungjawab atas penyerahan anak kemenakan kepada Ninik Mamak pihak perempuan. Di samping itu basiacuang dapat mendorong masyarakat terampil berbicara dalam menuturkan kata, maka haruslah tersusun rapi. Karena mulut merupakan senjata ampuh dalam menundukkan orang lain, tetapi mulut juga dapat melukai hati orang lain, seperti pepatah mengatakan mulutmu harimaumu, kalau luka karena pedang masih ada obat akan dicari, kalau bicara melukai hati seseorang kemana obat akan dicari. (Wawancara dengan Bapak Nas, tanggal 10 September 2014).

Tindakan pembicaraan basiacuang dalam adat perkawinan ini yaitu Ninik Mamak memulai pembicaraannya dengan pihak yang datang dengan bahasa yang halus dan sopan, dan menyerahkan tepak sirih atau ulur tepak 
kepada Ninik Mamak perempuan untuk dilihat, setelah itu penyerahan anak kemenakan dari Ninik Mamak laki-laki kepada Ninik Mamak perempuan, setelah penyerahan tersebut barulah urang sumondo mempersilakan makan kepada pihak yang datang. Akhir dari upacara adat basiacuang dalam pernikahan ini pamit meninggalkan tempat acara dan pulang ke rumah masingmasing oleh pihak Ninik Mamak pihak lakilaki. Apabila suatu acara sudah selesai dilaksanakan, pihak Ninik Mamak merasa bahwa tugasnya pada acara perhelatan penikahan telah selesai, untuk itu pihak Ninik Mamak dan undangan lainnya mohon izin pulang atau pamitan kepada tuan rumah. sesuai dengan pepatah adat "datang nak muko, pulang nampak pungguong” (datang tampak muka pulang tampak punggung). Proses penciptaan kelisanan tercipta dalam konteks budaya tradisional.

Konsep budaya tradisional sangat mementingkan kesopanan dalam berbahasa, dan ketertiban dalam berkomunikasi. Ini berkaitan dengan penyampaian teguran dan moral (Taslim dalam Zulfa, 2012). Hal ini terlihat pada penciptaan tuturan basiacuang, yang berisi nilai kesopanan dan kelancaran dalam berkomunikasi dengan masyarakat dan kaum adat pada tradisi upacara adat perkawinan Melayu Kampar.

\section{Kaidah Budaya dalam Tradisi Basiacuang pada Adat Perkawinan Melayu Kampar}

Dalam berkomunikasi, selain terikat oleh kaidah lingual, setiap anggota masyarakat tutur terikat pula oleh norma budaya masyarakatnya. Karena itu, dalam menjalankan aktivitas bertutur setiap anggota masyarakat tutur harus selalu menghargai dan menghormati norma-norma budaya masyarakat, yang kemudian direfleksikan dalam wujud tuturannya. Aktivitas bertutur dapat dikatakan sebagai praktik budaya, sedangkan wujud tindak tutur dapat dikatakan sebagai praktik budaya (Suyitno, 2006). Komunikasi merupakan aktivitas sosial yang dilakukan oleh anggota masyarakat tutur dalam berinteraksi dengan sesama sebagai produk budaya (Suparno, 2002). Budaya komunikasi itu dapat dikenali dari tuturan yang terungkap.

Tradisi basiacuang sebagai salah satu tradisi lisan dalam adat perkawinan masyarakat tutur Desa Kuok, Kecamatan Kuok, Kabupaten Kampar mencerminkan nilai-nilai budaya yang berlaku dalam masyarakat. Basiacuang itu penting dan bermanfaat karena dalam acara basiacuang itu terdapat bentuk-bentuk pesan yang merupakan nilai-nilai budaya yang berlaku dalam masyarakat (Husmiwati,2015). tokoh masyarakat yang mengatakan bahwa:

"Setiap kata-kata dalam basiacuang harus sesuai dengan norma-norma yang berlaku dalam adat Kampar, dan harus dipatuhi seperti adat lainnya pada umumnya. Orang yang pandai basiacuang akan diberikan tempat yang istimewa karena ia akan menerima orang datang (tamu) ketika ada helat adat (upacara). Orang yang pandai basiacuang dipandang lebih baik oleh masyarakat, seorang penutur basiacuang di dalam dirinya sudah tertanam nilai-nilai filosofi luhur sesuai alur yang patut (sesuai nilai dan norma)" (Wawancara dengan Bapak Amr., tanggal 24 September 2014).

Aspek kebudayaan dalam kajian etnografi komunikasi mencakup stuktur sosial, nilai, dan sikap, peta atau skema kognitif, proses enkulturasi (transmisi pengetahuan dan keterampilan) (Kuswarno, 2008).

Nilai budaya memunyai kaitan yang nyata dalam mengarahkan seseorang berperilaku secara verbal di dalam interaksi sosial. Secara tidak langsung faktor soial dan budaya berkaitan dengan pengekspresian tindak tutur dengan beragam modus. Sementara itu, ekspresi tindak tutur merupakan hubungan hasil perpaduan antara kompetensi kebahasaan yang dimiliki penutur, mitra tutur, latar, dan status. Apabila berbicara tentang penutur, mitra tutur dan keterkaitan mereka dengan nilai-nilai etika dan keyakinan budaya yang dianutnya, nilai budaya itu sebenarnya berakar pada kebutuhan dasar manusia dan keyakinan 
adalah dasar yang utama sebagai acuan untuk mengekspresikan tindak tutur.

Kaidah budaya penggunaan tradisi lisan basiacuang dalam adat perkawinan masyarakat tutur Melayu Kampar Desa Kuok dikonstruksikan dalam tabel 4.

Dalam tradisi lisan basiacuang sangat memegang aturan dan norma-norma yang berlaku di dalam adat, adanya rasa saling menghormati dan menghargai antarsesama, adanya rasa kerendahan hati (tawadu'), memegang teguh permusyawarahan, ketelitian dan kecermatan, taat dan patuh pada adat. Fungsi basiacuang sebagai tradisi lisan dalam masyarakat Melayu Kampar antara lain mendorong masyarakat untuk terampil berbicara, mempertinggi sopan santun, memberikan pelajaran atau nasihat kepada masyarakat, sebagai sarana untuk bersilaturahmi, mendorong masyarakat untuk selalu bekerja sama dan saling menolong dalam kehidupan sehari-hari (Yunus, 2013). Hal ini sejalan dengan apa yang diungkapkan oleh Pudentia (2007) ada hal-hal yang berperan dalam proses penciptaan kelisanan yaitu faktor rangsangan dari luar dalam bentuk reaksi dan tanggapan masyarakat sekitar, riwayat hidup, imajinasi, dan reaksireaksi pribadi si penutur pada kehidupannya.

Tabel 3

Kaidah Interaksi Sosial Prosesi Lisan Basiacuang dalam Adat Perkawinan Masyarakat Tutur Melayu Kampar

\begin{tabular}{|c|c|c|}
\hline No. & Prosesi Lisan Basiacuang & Kaidah Interaksi \\
\hline 1 & $\begin{array}{l}\text { Basiacuang meminta izin menyampaikan } \\
\text { maksud }\end{array}$ & $\begin{array}{l}\text { Ninik Mamak pihak laki-laki bertanya kepada pihak Ninik } \\
\text { Mamak pihak perempuan memohon izin kepada seluruh } \\
\text { yang hadir dalam acara adat perkawinan untuk } \\
\text { menyampaikan maksud dan tujuan. }\end{array}$ \\
\hline 2 & Basiacuang ulur/penyerahan tepak sirih & $\begin{array}{l}\text { Ninik Mamak pihak laki-laki menyuguhkan sirih kepada } \\
\text { tuan rumah dan meminta Datuk Paduko Tan pihak } \\
\text { perempuan untuk melihat, mengambil, dan memakan sirih } \\
\text { tersebut, sebagai rasa penghargaan terhadap orang lain. } \\
\text { Simbol tepak sirih melambangkan rasa tulus hati dalam } \\
\text { menyambut tamu dan juga sebagai lambang persaudaraan. }\end{array}$ \\
\hline
\end{tabular}

3 Basiacuang penyerahan anak kemenakan secara adat.

$4 \quad$ Basiacuang mempersilakan makan

$5 \quad$ Basiacuang buka selo atau pamitan minta izin pulang.
Setelah Ninik Mamak pihak laki-laki datang ke rumah pihak perempuan dan telah menyuguhkan sirih, barulah ninik mamak menyerahkan anak kemenakannya kepada pihak perempuan.

Setelah Ninik Mamak dalam persukuan mengulurkan tepak dan penyerahan anak kemenakan, kemudian orang sumando pihak perempuan menyuguhkan dan mempersilakan makan sebagai rasa hormat dan terimakasih sudah hadir dalam acara adat perkawinan anak kemenakan.

Ninik Mamak merasa bahwa tugasnya pada acara adat perkawinan telah selesai, untuk itu pihak Ninik Mamak dan undangan lainnya mohon izin pulang atau pamitan kepada tuan rumah (pihak perempuan). 


\section{Tabel 4}

Kaidah Budaya Tradisi Lisan Basiacuang dalam Adat Perkawinan Masyarakat Tutur Melayu Kampar

\begin{tabular}{|c|c|c|}
\hline No. & Tindak Komunikasi Tradisi Lisan Basiacuang & Nilai Budaya \\
\hline 1 & $\begin{array}{l}\text { Pembukaan basiacuang pada prosesi adat perkawinan dimulai dari } \\
\text { tamu dengan menyapa Datuk, Ninik Mamak, dan semua yang hadir } \\
\text { sebagai pertanda semua yang hadir dihargai oleh tamu dengan } \\
\text { menyebutkan gelar adatnya. }\end{array}$ & $\begin{array}{l}\text { Nilai kerendahan hati dan } \\
\text { penghargaan kepada orang lain. }\end{array}$ \\
\hline 2 & $\begin{array}{l}\text { Dalam basiacuang terungkap azas demokrasi dan perlakuan yang } \\
\text { sama dari tamu untuk pembukaan bagi setiap orang karena ketika akan } \\
\text { memutuskan sesuatu harus disepakati terlebih dahulu oleh semua } \\
\text { anggota yang hadir dalam acara basiacuang tersebut dan diharapkan } \\
\text { mengeluarkan atau mengemukakan pendapat tentang sesuatu masalah } \\
\text { yang dibicarakan dalam perundingan adat perkawinan }\end{array}$ & Nilai musyawarah \\
\hline 3 & $\begin{array}{l}\text { Di dalam tradisi basiacuang masyarakat melayu Kampar disampaikan } \\
\text { oleh dua penutur (kepala persukuan) masing-masing kedua belah } \\
\text { pihak yaitu Ninik Mamak pihak laki-laki dan Ninik Mamak pihak } \\
\text { perempuan secara sahut menyahut. Di dalam dialog itu selalu ada aba- } \\
\text { aba untuk memberitahu kepada pihak lain, bahwa penutur akan } \\
\text { memulai acara kepada semua pihak. Penutur yang satu memberi } \\
\text { isyarat (dengan kata-kata) bahwa lawan dialognya bisa menjawab. } \\
\text { Jika lawan bicaranya akan menjawab langsung, maka sering } \\
\text { diucapkan kalimat tanya, seperti "iyo sadetu kato yang disembahkan } \\
\text { ka Datuk?". }\end{array}$ & Nilai ketelitian dan kecermatan \\
\hline 4 & $\begin{array}{l}\text { Dalam adat perkawinan ketika tamu yang datang pihak laki-laki harus } \\
\text { membawa beberapa peralatan tepak sirih lengkap yang telah diadatkan } \\
\text { dengan isinya yaitu: sirih, gambir, sadah, pinang dan tembakau. Tepak } \\
\text { sirih itu diketengahkan pada orang banyak dan dipersilahkan untuk } \\
\text { memakan sirih. Melalui pembicaraan basiacung, acara tepak sirih ini } \\
\text { mencerminkan kaidah dan kehalusan budi menyampaikan maksud di } \\
\text { hadapan tamu dan melambangkan rasa tulus hati dalam menyambut } \\
\text { tamu dan juga sebagai lambang persaudaraan }\end{array}$ & $\begin{array}{l}\text { Nilai ketaatan dan kepatuhan } \\
\text { pada adat }\end{array}$ \\
\hline
\end{tabular}

Sumber: Hasil Penelitian 2014.

\section{PENUTUP}

\section{Simpulan}

Bertolak dari hasil dan pembahasan penelitian ini, dapat disimpulkan bahwa kaidah linguistik tradisi lisan basiacuang pada adat perkawinan masyarakat tutur Melayu Kampar di Desa Kuok mencakup pengetahuan dalam penggunaan dan interpretasi bahasa dalam suatu masyarakat tutur. Basiacuang merupakan karya sastra lisan dalam masyarakat Melayu Kampar, yang mengutamakan keindahan pemakaian bahasa yang disampaikan penutur. Seorang penutur basiacuang atau kepala persukuan
Ninik Mamak harus mengerti nilai-nilai dan norma-norma dalam masyarakat, dan penggunaan bahasa yang halus, sopan, lembut sehingga bisa dipahami oleh lawan bicaranya, agar tidak menyinggung perasaan salah satu pihak.

Kaidah interaksi sosial tradisi basiacuang dalam adat perkawinan masyarakat tutur Melayu Kampar ditandai dengan adanya interaksi antara kedua belah pihak, baik itu dari pihak laki-laki maupun pihak perempuan. Dalam diri penutur basiacuang sudah tertanam nilai-nilai dan norma-norma menurut alur yang patut di mana sebagai penutur harus dapat membaca situasi kondisi di manapun si penutur itu berada. Dalam pikirannya sudah ada isi 
tuturan dalam bertutur basiacuang, sehingga apa yang disampaikannya bisa dimengerti oleh lawan bicaranya. Dalam hal ini kepala persukuan Ninik Mamaklah yang berperan penting dalam basiacuang, karena mereka sebagai tokoh adat dalam suatu daerah untuk membimbing anak kemenakan dalam persukuannya sampai ke jenjang pernikahan.

Kaidah budaya tradisi lisan basiacuang dalam adat perkawinan masyarakat tutur melayu Kampar merupakan pengetahuan tentang menggunakan dan mengintepretasikan kebudayaan dalam suatu masyarakat tutur. Nilai kerendahan hati (tawadu) dan penghargaan terhadap orang lain terlihat saat sebelum seorang penutur hendak menyampaikan maksud kedatangannya kepada orang lain, maka orang tersebut menyapa semua yang hadir dalam acara basiacuang ini dengan menyebutkan gelar adatnya. Nilai musyawarah tradisi basiacuang memerlihatkan dialog yang terjadi secara demokratis di mana pendapat individu tidak diutamakan dalam basiacuang, karena selalu melibatkan semua pihak dalam mengambil suatu kata mufakat. Nilai ketelitian dan kecermatan dilakukan antara tuan rumah dan tamu yang bertujuan agar tidak terjadi kesalahpahaman dan untuk meyakinkan bahwa ia tidak salah mendengar apa yang diucapkan oleh penutur dengan lawan bicaranya. Nilai taat dan patuh pada adat, yang dilakukan antara tuan rumah dan tamu dengan tujuan agar tetap menuruti atau menjalankan adat yang berlaku, sehingga nilai taat dan patuh pada adat tersebut tidak hilang begitu saja. Berhasil atau tidaknya tradisi lisan basiacuang pada adat perkawinan masyarakat tutur Melayu Kampar tergantung dari keahlian dan kefasihan penutur dalam menerapkan nilai-nilai dalam basiacuang.

\section{Saran}

Tradisi lisan basiacuang sebagai bentuk kearifan lokal masyarakat Melayu Kampar harus dapat dipertahankan dari generasi ke generasi agar budaya tradisi basiacuang tidak hilang begitu saja. Penelitian lanjutan mengenai tradisi lisan basiacuang dapat dilakukan dengan pendekatan interaksi simbolik dan fenomenologi dalam komunikasi intrabudaya.

\section{DAFTAR PUSTAKA}

Buku:

Ibrahim, Abd. Syukur. (1994). Panduan Penelitian Etnografi Komunikasi. Surabaya Indonesia: Usaha Nasional.

Kleden, Ignas. (2004). Sastra Indonesia dalam Enam Pertanyaan: Esai-Esai Sastra dan Budaya. Jakarta: PT Pustaka Utama Grafiti.

Kuswarno, Engkus. (2011). Etnogarafi Komunikasi. Bandung: Widya Padjadjaran.

Liliweri, Alo. (2003). Makna Budaya dalam Komunikasi Antarbudaya.

Yogyakarta: Lkis.

Lord, Albert, B. (2000), The Singer Of Tales, Second Edition, London: Harvard University Press.

Milles Mb, Huberman AM. (2007). Analisis

Data Kualitatif. Rohidi TR, penerjemah. Jakarta (ID): UI Press. Terjemahan: Qualitative Data Analysis.

Moleong, Lexy. (2005). Metode Penelitian Kualitatif. Bandung: Remaja Rosdakarya

Muriel, (2003). The Ethnography Of Communication: An Introduction. Southampton: The Camelot Press.

Mulyana, Deddy, dan Rakhmat. (2010). Komunikasi Antarbudaya: Pedoman Berkomunikasi dengan Orang-Orang Berbeda Budaya. Bandung: PT. Remaja Rosdakarya

Nasrullah, Rulli. (2012). Komunikasi Antarbudaya di Era Budaya Siber. Jakarta: Kencana Prenada Media Group

Ruslan, Rosadi. (2010). Metode Penelitian Public Relation dan Komunikasi. Jakarta: Rineka Cipta. 
Suparno. (2000). Budaya Komunikasi yang Terungkap dalam Wacana Bahasa Indonesia. Malang: Universitas Negeri Malang

Syarfi, dkk. (2011). Siacuong (Sisombau) dalam Masyarakat Adat Kampar. Pemerintah Kabupaten Kampar: Dinas Pariwisata dan Kebudayaan Kabupaten Kampar

\section{Jurnal:}

Andung, Petrus. (2010). Komunikasi Ritual Natoni Masyarakat Adat Boti Dalam di Nusa Tenggara .Jurnal Ilmu Komunikasi, Yogyakarta, Vol. 8 No. 1 Januari-April. Hal 1-103.

Nugroho, Lestari, dan Wiendijarti. (2012). Pola Komunikasi Antarbudaya Batak dan Jawa di Yogyakarta. Jurnal Komunikasi Aspikom Yogyakarta, Vol. 1 No. 5 Juli, Hal. 383-464.

Suyitno, Imam. (2006). Komunikasi Antaretnik dalam Masyarakat Tutur Diglosik: Kajian Etnografi Komunikasi Etnik Using. Jurnal HUMANIORA, Vol. 18 No. 3 Oktober, Hal 263-270.

Yunus, Mohd. (2013). Tradisi Basiacuang dalam Masyarakat Adat Limo Koto Kampar. Jurnal Menara, Vol. 12 No. 2 Desember, Hal.92-114.

\section{Skripsi / Tesis / Disertasi:}

Husmiwati, Kurnia. (2015). Pemolaan Komunikasi Tradisi Basiacuang Sebagai Bentuk Kearifan Lokal dalam Upacara Pernikahan Masyarakat Melayu Kampar Provinsi Riau (Studi Etnografi Komunikasi Tradisi Basiacuang di Desa Kuok Kecamatan Kuok Kabupaten Kampar). Skripsi. Universitas Riau.

Pundentia, (2007). Tradisi Lisan Makyong. Disertasi. Universitas Indonesia.

Zulfa. (2012). Tradisi Basiacuang pada Masyarakat Melayu Kampar-Riau. Tesis.Universitas Indonesia. 